\title{
KARAKTERISTIK TERMOPLASTIK ELASTOMER DARI KARET ALAM DAN POLIPROPILENA DENGAN PENAMBAHAN CARBON BLACK FILLER
}

\author{
ELASTOMERIC THERMOPLASTIC CHARACTERISTICS OF NATURAL RUBER AAND \\ POLYPROPYLENEWITH THE ADDITION OF CARBON BLACK FILLER
}

\author{
Indah Agus Setiorini ${ }^{1}$ \\ 1Teknik Pengolahan Migas Politeknik Akamigas Palembang, 30257, Indonesia \\ Corresponding Author E-mail: indahagussetiorini_sukarman@yahoo.co.id
}

\begin{abstract}
Elastomer Thermoplastic (ETP) is a polymer that has elastic and thermoplastic properties that have long been used in everyday use. Elastomer thermoplastics produced are based on Natural Rubber and Polypropylene for industrial use. One effort to develop ETP products that have been produced into superior materials and are accepted by the automotive industry as well as the medical equipment industry is carried out research to study the effect of carbon black filler on PP/NR composites. The method used in this research is the Polypropylene degradation process using Benzoil Peroxide. The degradation process is carried out at $160{ }^{\circ} \mathrm{C}$ and takes 10 minutes. The composite variable PP/NR/CB are (30: 70: 0)\% wt, (30: 68: 2)\% wt, (30: 66: 4)\% wt and (30: 64: 6)\% wt. The characteristics tested include physical and mechanical properties. The results obtained indicate that the composite physical properties test in the form of density increases with increasing filler content, whereas the composite mechanical properties test in the form of tensile strength test increases with increasing fiiler levels and mechanical tests in the form of elongation at break and oil resistance decreases with increasing filler content. The best value is obtained from composites with $\mathrm{PP} / \mathrm{NR} / \mathrm{CB}$ ratio (30: 64: 6)\% wt in the form of mechanical properties tensile strength of $1,79 \mathrm{~N} / \mathrm{mm}^{2}$ and the best break extension is obtained from composites with PP/NR/CB ratio (30: 70: 0)\% by weight 277,38\%
\end{abstract}

Keywords: Elastomer Thermoplastic, Natural Rubber, Polypropylene, Carbon Black, Filler

Abstrak: Termoplastik Elastomer (TPE) adalah polimer yang memiliki sifat elastis dan termoplastis yang telah lama dimanfaatkan dalam keperluan sehari-hari. Termoplastik elastomer yang dihasilkan berbahan dasar Karet Alam dan Polipropilena untuk penggunaan industri. Salah satu usaha untuk mengembangkan produk TPE yang telah dihasilkan menjadi bahan yang unggul dan diterima oleh industri otomotif serta industri alat kesehatan maka dilakukan penelitian untuk mempelajari pengaruh carbon black filler terhadap komposit PP/NR. Metode yang digunakan dalam penelitian ini adalah dengan proses degradasi Polipropilena menggunakan Benzoil Peroksida. Proses degradasi dilakukan pada suhu $160^{\circ} \mathrm{C}$ dan waktu 10 menit. Variabel campuran komposit PP/NR/CB yaitu (30:70:0)\% wt, (30:68:2)\% wt, (30:66:4)\% wt dan (30:64:6)\% wt. Karakteristik yang di uji meliputi sifat fisik dan sifat mekanik. Hasil yang diperoleh menunjukkan bahwa uji sifat fisik komposit berupa densitas semakin menurun seiring bertambahnya kadar filler, sedangkan uji sifat mekanik komposit berupa uji kuat tarik semakin meningkat dengan bertambahnya kadar fiiler dan uji mekanik berupa perpanjangan putus dan ketahanan terhadap minyak semakin menurun seiring bertambahnya kadar filler. Nilai terbaik diperoleh dari komposit dengan perbandingan PP/NR/CB (30:64:6)\% wt berupa sifat mekanik tensile strength sebesar $1,79 \mathrm{~N} / \mathrm{mm}^{2}$ dan perpanjangan putus terbaik diperoleh dari komposit dengan perbandingan PP/NR/CB (30:70:0)\% berat sebesar 277,38\%.

Kata Kunci : Termoplastik Elastomer, Karet Alam, Polipropilena, Carbon Black, Filler

\section{PENDAHULUAN}

Termoplastik Elastomer (TPE) yaitu polimer yang memiliki sifat elastis dan termoplastis. TPE telah lama dimanfaatkan dalam keperluan sehari-hari dan pemakaiannya semakin meningkat setiap tahunnya karena memiliki keunggulan dibandingkan vulkanizat elastomer karena tidak memerlukan crosslink agent, proses pengerjaannya lebih konvensional dan berlangsung lebih cepat, serta barang jadinya dapat didaur ulang atau diolah kembali (Deswita, dkk, 2006).

Komposit adalah suatu jenis bahan baru hasil rekayasa yang terdiri dari dua atau lebih bahan dimana sifat masing-masing bahan berbeda satu sama lainnya baik itu sifat kimia maupun fisikanya dan tetap terpisah dalam hasil akhir bahan tersebut (bahan komposit). 
Telah menjadi fenomena yang penting pada tahun-tahun terakhir ini untuk mendapatkan suatu bahan dengan sifat-sifat tertentu seperti : sifat mekanik, sifat fisik, termal dan kemampuan proses yang baik yang tidak dapat ditemukan dari masing-masing komponen. Pertimbangan biaya merupakan salah satu alasan utama pada industri yang menyangkut bahan polimer selain dari alasan pencampuran.. Apabila suatu bahan dapat diproduksi dengan biaya murah dan menghasilkan spesifikasi yang memenuhi kebutuhan, maka produk tersebut akan kompetitif di pasar (Halimatuddahliana, dkk, 2008).

Polipropilena atau polipropena (PP) adalah sebuah polimer termo-plastik yang dibuat oleh industri kimia dan digunakan dalam berbagai aplikasi, diantaranya pengemasan, tekstil (contohnya tali, pakaian, dan karpet), alat tulis, perlengkapan labolatorium, komponen otomotif, dan uang kertas polimer. Polipropilena mempunyai specific gravity rendah dibandingkan dengan jenis plastik lain.

Karet alam adalah senyawa hidrokarbon yang merupakan polimer alam hasil penggumpalan lateks alam dan merupakam makromolekul poliisoprena $\left(\mathrm{C}_{5} \mathrm{H}_{8}\right)$ yang bergabung secara ikatan kepala ke ekor (head to tail). Karet alam adalah elastomer alam yang berat molekulnya relatif tinggi dan sulit dicetak dalam keadaan panas tanpa perlakuan khusus. Karet alam adalah salah satu bahan untuk membuat termoplastik elastomer yang diolah dengan cara konvensional atau dengan teknik radiasi (Deswita, dkk, 2006). Campuran antara elastomer dan termoplastik (bahan termoplastik elastomer) dapat menghasilkan bahan dengan spesifikasi teknik yang diharapkan. Salah satu contoh termoplastik elastomer yang sangat populer saat ini adalah termoplastik elastomer polipropilene/etilenepropilene diene terpolimer (PP/EPDM) yang mempunyai beberapa keunggulan sifat, seperti tahan terhadap benturan (impact resistance), tahan terhadap bahan kimia (good chemical resistance), stabilitas termal yang baik (good thermal stability) (Halimatuddahliana, dkk, 2008).

Campuran kedua bahan ini dapat menghasilkan produk industri kendaraan seperti bumper, panel pintu, kibasan lumpur (mudflaps) dan bagian dalam mobil (interior). Campuran antara PP dan EPDM kadang kala tidak memerlukan bahan kuratif seperti bahan sambung silang (crosslink). Interaksi yang baik antara EPDM dan PP disebabkan oleh struktur kimia EPDM yang juga mengandung gugus propilena sehingga campuran PP/EPDM lebih compatible dibandingkan dengan PP/NR. EPDM adalah karet sintesis yang harus diimport dari luar negeri sehingga biaya pengadaannya relatif cukup mahal. Karet alam (NR) adalah sumber asli negara yang banyak terdapat di Indonesia sehingga penggantian EPDM dengan NR merupakan langkah yang tepat apabila dipandang dari segi ekonomi. Namun hasil penelitian terdahulu menunjukkan terjadinya penurunan sifat mekanik (tensile test, oil resistance test) bila EPDM diganti dengan NR dibandingkan dengan campuran PP/EPDM (Halimatuddahliana,dkk., 2008). Hal ini disebabkan karena campuran PP/NR kurang serasi dibandingkan dengan PP/EPDM. Dari penelitian terdahulu yang menunjukkan beberapa sifat mekanik yang tidak tercapai maka peneliti melakukan penambahan carbon black filler yang dapat meningkatkan sifat mekanik campuran PP/NR menggunakan metode grafting. Metode ini dipilih dengan pertimbangan lebih konvensional dimana kondisi operasi tidak terlalu tinggi, yaitu 160 ${ }^{\circ} \mathrm{C}$ dibandingkan metode yang lain (Hidayani, 2010).

Sejauh ini TPE berbasis PP/NR belum dapat dikembangkan secara komersial karena spesifikasi material tersebut belum dapat bersaing dengan TPE berbasis karet sintetik. Beberapa peneliti sudah mengembangkan metode-metode untuk dapat meningkatkan sifat mekanik campuran PP/NR, diantaranya adalah proses vulkanisasi dinamik dengan pemberian bahan-bahan sambung silang (crosslink) (Halimatuddahliana, dkk, 2008; Bahruddin, dkk. 2007), pencangkokan 
(grafting) secara polimerisasi emulsi antara NR dengan monomer stirena dan metil metakrilat (Suhardjo, dkk. 2011), pencangkokan (grafting) secara polimerisasi emulsi antara NR dengan monomer stirena dan metil metakrilat dengan menggunakan inisiator Potassium Persulfate dan Ammonium Peroxydisulfate (Sondari, dkk. 2010) ,penambahan filler Carbon Black (CB) (Bahruddin, dkk, 2010), Proses Blending antara TPE berbasis karet alam (NR) dengan PE dan TPE berbasis karet alam (NR) dengan PP (Deswita, dkk. 2006), Proses Blending antara PP/EPDM/NR dan PP/EPDM/ENR25 (Halimatuddahliana dan Ismail, 2003), Pencangkokan (grafting) antara Polystirene dengan Maleat Anhidrid menggunakan inisiator benzoil peroksida (Sukatik, 2012), Pembuatan termoplastik elastomer dari campuran elastomer berupa karet alam dengan termoplastik berupa metil metakrilat (MMA) secara bersama-sama diiradiasi sinar gamma secara optimal dengan $\mathrm{Pb}_{3} \mathrm{O}_{4}$ sebagai Filler (Sudirman, dkk. 2000). Namun sejauh ini metode-metode tersebut belum dapat menghasilkan peningkatan sifat mekanik sebagaimana diharapkan.

Metode lain yang dapat dikembangkan adalah dengan menambah komponen filler dalam campuran polimer tersebut. Carbon Black (CB) adalah salah satu jenis filler yang sudah umum digunakan untuk meningkatkan sifat mekanik karet tervulkanisasi. Namun demikian, beberapa peneliti masih terus mengevaluasi penggunaan $\mathrm{CB}$ untuk meningkatkan performa karet tervulkanisasi (Bahruddin, dkk. 2010).

Pemanfaatan CB sebagai filler untuk meningkatkan sifat mekanik TPE berbasis PP/NR belum banyak dilakukan. Merujuk pada TPE berbasis PP dan karet sintetik EPDM yang sifat mekaniknya dapat ditingkatkan dengan penambahan CB filler (Bahruddin, dkk. 2010), penelitian ini bertujuan untuk meningkatkan sifat fisik (morfologi campuran dan densitas) dan sifat mekanik (uji kuat tarik, uji perpanjangan putus dan uji ketahanan minyak) $P P / N R$ dengan penambahan CB filler. Sistem campuran yang dibuat juga menggunakan kompatibiliser MAg-PP, seperti penelitian yang dilakukan sebelumnya (Deswita, dkk. 2006).

Berdasarkan penelitian terdahulu menunjukkan terjadinya penurunan sifat mekanik (tensile test, oil resistance test) bila EPDM diganti dengan NR dibandingkan dengan campuran PP/EPDM. Hal ini disebabkan karena campuran PP/NR kurang cocok dibandingkan dengan PP/EPDM (Halimatuddahliana, 2008). Berdasarkan penurunan sifat mekanik yang tidak tercapai, maka peneliti melakukan penambahan carbon black filler yang dapat meningkatkan sifat mekanik campuran PP/NR menggunakan metode grafting. Selanjutnya melakukan analisa sifat fisik (densitas dan morfologi campuran) dan sifat mekanik (uji kuat tarik, uji perpanjangan putus dan uji ketahanan minyak) dari produk akhir setelah dilakukan penambahan komponen filler dalam campuran PP/NR.

\section{TEORI DASAR}

\subsection{Material}

\subsubsection{Termoplastik Elastomer (TPE)}

Termoplastik Elastomer (TPE) adalah suatu campuran atau senyawa polimer yang merupakan gabungan dari sifat-sifat proses termoplastik dengan tampilan fungsi elastomer konvensional, dan temperatur lelehnya menunjukkan bahwa karakter termoplastik yang memungkinkan untuk dibentuk kembali menjadi barang jadi, dalam skala suhu tertentu selama proses pembuatan memiliki perilaku elastomer tanpa ikatan silang. Cara pembuatannya dapat dilakukan pada fase leleh maupun fase emulsi. Selama beberapa tahun terakhir ini perkembangan TPE telah mendapat banyak perhatian dibidang pengetahuan dan teknologi polimer. Sekarang TPE telah menjadi salah satu barang polimer penting dalam perdagangan.

TPE terdiri dari: Polyolefin, Polistirenkopolimer dan Poliuretan. Sedangkan TPE berbasis campuran karet - plastik dapat dibagi menjadi dua kelas utama, yaitu: TPO (termoplastik olefin) dan TPV (termoplastik vulkanisasi). TPO dapat dibuat secara mudah 
dan biaya yang relatif murah karena dispersi phase karet tidak terjadi secara ikat silang, sebaliknya TPV memerlukan proses lebih komplek karena dispersi fase karet harus terjadi secara ikat silang selama proses pencampuran, sebagian besar melalui vulkanisasi dinamik atau proses ikat silang insitu. TPE dapat dibuat dengan cara pencampuran pada fase emulsi atau pada fase leleh dari polimer pembentuknya. Pembuatan TPE ada bermacam-macam cara tergantung jenis polimer pembentuk, kompatibilizer, filler dan aditif lainnya.

Dalam penyelidikan yang melibatkan bahan termoplastik dan karet alam adalah dengan penemuan bahan yang dikenali sebagai Termoplastik elastomer, yang merupakan kopolimer blok dengan sifat elastik pada suhu kamar sampai kira-kira $70{ }^{\circ} \mathrm{C}$. Termoplastik elastomer dapat diproses seperti termoplastik konvensional tanpa perlu dilakukan proses vulkanisasi. Sifat elastik ini disebabkan sifat ikatan silang fisik yang dihasilkan dari pada daya antara molekul seperti ikatan hidrogen. Ikatan-ikatan ini akan terputus jika Termoplastik elastomer dipanaskan melebihi suhu tertentu dan terbentuk kembali apabila didinginkan. Berbagai jenis campuran polimer yang semakin mendapat perhatian seperti : campuran elastomer-elastomer, plastik-plastik dan elastomer-termoplastik elastomer karena ciri-ciri pemprosesannya yang sama seperti termoplastik dan sifat tekniknya yang sama seperti elastomer tervulkanisir (Bukit, 2012).

Penggunaan elastomer yang murah dan termoplastik yang mahal akan menghasilkan pengurangan dari segi biaya bahan, selain itu dapat meningkatkan beberapa sifat mekanik seperti kekuatan hantaman (impak) dan sifat lainnya. Di samping itu, penambahan bahan aditif yang murah juga dapat mengurangi biaya bahan, termasuk penggunaan bahan pengisi (filler) sebagai penguat dan bahan pengisi yang bukan sebagai penguat. Penelitian sebelumnya telah mengkaji tentang vulkanisasi dinamik campuran karet alam dan polipropilena dengan bahan pengisi serbuk kayu karet. Hasil penelitiannya menunjukkan bahwa dengan peningkatan dari 0 hingga $2 \%$ wt sulfur dapat meningkatkan kekuatan tarik, modulus Young dan modulus lentur (Bukit, 2012).

Penelitian terdahulu juga mengkaji dengan menambahkan bahan kompatibiliser propilena-etilena-akrilik acid (PPEAA) terhadap sifat-sifat mekanik dan penggembangannya (sweling) dengan menggunakan campuran karet alam (NR) dan LLDPE dengan bahan pengisi (filler) abu sekam padi putih (ASPP), hasil penelitiannya diperoleh bahwa peningkatan ASPP di dalam campuran NR/LLDPE telah mengakibatkan penurunan terhadap kekuatan tarik, dan penambahan bahan manakala modulus tarik dan kekerasannya meningkat (Bukit, 2012). Pada penambahan bahan pengisi yang sama dan dengan kehadiran PPEAA, kekuatan tarik, modulus tarik, kekerasan dan perpanjangan putus meningkat apabila penambahan bahan menurun.

\subsubsection{Jenis-jenis Termoplastik Elastomer (TPE)}

Termoplastik elastomer secara komersial dapat digolongkan pada dua kelompok yang utama, yaitu:

1. Kopolimer blok, dan

2. Polimer campuran .

a. Polimer

Polimer adalah senyawa molekul besar berbentuk rantai atau jaringan yang tersusun dari gabungan ribuan hingga jutaan unit pembangun yang berulang. Bahan pengemas, mainan anak-anak, tekstil, peralatan rumah tangga, peralatan elektronik, peralatan transportasi hingga peralatan kedokteran, plastik pembungkus, botol plastik, styrofoam, nilon, dan pipa paralon termasuk material yang disebut polimer. Saat ini pemanfaatan polimer sudah meliputi berbagai aspek kehidupan. Industri polimer berkembang pesat selama beberapa dekade terakhir, bahkan industri polimer dapat dipandang sebagai industri dasar pada negara industri.

Unit kecil berulang yang membangun polimer disebut monomer. Sebagai contoh, polipropilena (PP) adalah polimer yang tersusun dari monomer propena. Di alam banyak sekali terdapat polimer organik atau 
polimer alam, tetapi karena perkembangan teknologi yang semakin maju, sekarang ini banyak ditemukan polimer anorganik atau yang biasa disebut polimer sintetik.

Polimer yang berasal dari alam atau polimer organik misalnya: karet alam, sellulosa dan protein. Sedangkan yang termasuk polimer anorganik atau polimer sintetik misalnya: PVC dan teflon. Para ahli kimia telah berhasil menggali pengetahuan yang berguna bagi polimer sintetik untuk memenuhi berbagai tujuan dan menyebabkan industri polimer berkembang dengan pesat di abad ini. Hal tersebut ditandai dengan semakin berkembangnya teknologi polimer sintetik dalam berbagai segi kehidupan. Polimer sintetis ini sangat berguna bagi manusia dalam berbagai bidang kehidupan. Tetapi di sisi lain polimer sintetik juga dapat menimbulkan ancaman bagi kelestarian alam, karena sebagian besar polimer sintetik yang sudah tidak digunakan lagi dan dibuang tidak bisa diuraikan oleh alam. Untuk itu, sekarang ini banyak dikembangkan pembuatan polimer sintetik yang ramah lingkungan sehingga polimer tersebut tidak membahayakan lingkungan hidup kita.

b. Polipropilena

Polipropilena merupakan polimer kristalin yang dihasilkan dari proses polimerisasi gas propilena, dimana propilena mempunyai specific gravity rendah dibandingkan dengan jenis plastik lain. Sebagai perbandingan dapat dilihat pada Tabel 1. Polipropilena memiliki titik leleh yang cukup tinggi $149-170^{\circ} \mathrm{C}$, sedangkan titik kristalisasinya antara $130-135 \mathrm{C}$.

Tabel 2.1. Perbandingan Specific Gravity Dari Berbagai Material Plastik

\begin{tabular}{|c|c|}
\hline Resin & Specific Gravity \\
\hline PP & $0,85-0,90$ \\
\hline LDPE & $0,91-0,93$ \\
\hline HDPE & $0,93-0,96$ \\
\hline Polistirena & $1,05-1,08$ \\
\hline
\end{tabular}

Ketahanan polipropilena terhadap bahan kimia (chemical resistance) sangat tinggi, tetapi impact strength-nya rendah. Polipropilena adalah salah satu dari bahan termoplastik yang memiliki sifat-sifat yang diinginkan sehingga membuat bahan ini serbaguna dan menjadi salah satu dari termoplastik komersial terpenting, konsumsinya meningkat dengan cepat dibandingkan polimer termoplastik lainnya.

c. Karet alam

Karet alam berasal dari Brazil dengan nama ilmiah Hevea Brasilliensis. Karet alam merupakan senyawa hidrokarbon yang mengandung atom karbon (C) dan atom hidrogen $(\mathrm{H})$ dan merupakan senyawa polimer dengan isoprena sebagai monomernya. Rumus empiris karet alam adalah $\left(\mathrm{C}_{5} \mathrm{H}_{8}\right) \mathrm{n}$, diperlihatkan pada Gambar 2.1. Dengan perbandingan atom-atom karbon dan hidrogen adalah 5 : 8 dan $n$ menunjukkan banyaknya monomer dalam rantai polimer.

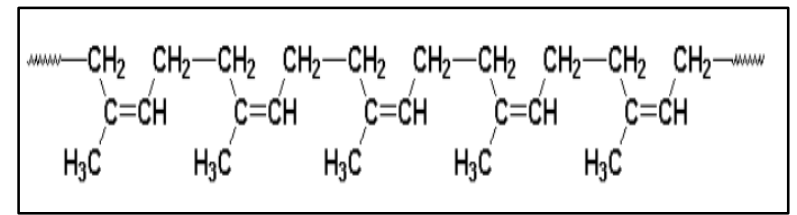

Gambar 2.1 Struktur Kimia Poliisoprena

Karet atau elastomer merupakan salah satu jenis polimer yang memiliki perilaku khas yaitu memiliki daerah elastis non-linear yag sangat besar. Perilaku tersebut memiliki kaitan dengan struktur molekul karet yang memiliki ikatan silang (cross link) antar rantai molekul. Ikatan silang ini berperan sebagai 'pengingat bentuk' (shape memory) sehingga karet dapat kembali ke bentuk dan dimensi asalnya pada saat mengalami deformasi dalam jumlah yang sangat besar.

Sifat fisik hidrokarbon karet dipengaruhi oleh panjang dan ukuran dari rantai molekul polimer. Berat molekul (BM), panjang rantai molekul dan penampang dari suatu molekul sangat menentukan sifat teknis seperti viskositas dan sifat fisika vulkanisat seperti tegangan putus dan perpanjangan putus. Pada umumnya semakin tinggi Berat Molekul (BM) hidrokarbon karet, semakin 
panjang rantai molekul dan semakin tinggi tahanan terhadap aliran, dengan kata lain karetnya lebih viskous dan keras. Ikatan C-C di dalam rantai polimer karet dapat merubah sudut ikatannya karena pengaruh fisik dari luar. Molekul-molekul yang panjang di alam pada umumnya tidak lurus tetapi melingkar seperti spiral/siklis. Hal ini memberikan sifat fleksibel, dapat ditarik (pada batas-batas tertentu) atau ditekan dan memiliki sifat lentur.

Keunggulan yang dimiliki oleh karet alam antara lain, memiliki daya elastisitas yang tinggi (high elasticity), plastisitas yang baik sehingga pengolahannya mudah, memiliki daya aus yang tinggi, ketahanan tusuk yang tinggi (high cut growth), ketahanan koyak (tear resistance) yang tinggi dan tidak mudah panas (low heat build up) serta mempunyai cengkeraman yang tinggi sehingga cocok untuk ban radial dan ban pesawat terbang.

Karet alam adalah salah satu bahan penting yang digunakan secara luas dalam aplikasi teknik penggunaannya hal tersebut disebabkan karena kelembutan alaminya dan kemudahan pembentukannya. Meskipun demikian, bahan pengisi perlu ditambahkan dengan maksud untuk menyiasati sifat-sifat alami yang tidak dikehendaki sehingga didapat suatu produk seperti yang diinginkan. Jenis dan jumlah bahan pengisi ditentukan oleh karakteristik produk yang diinginkan dan kelenturannya. Bahan pengisi adalah campuran dari berbagai material termasuk di dalamnya arang hitam (carbon black), bahan mineral seperti montmorillonite (tanah liat), dan kalsium karbona.

Bahan pengisi pada industri karet, tanah liat adalah mineral murah dan telah menjadi bagian penting dalam industri karet dimana penggunaannya sebagai bahan pengisi ekonomis untuk memodifikasi penciptaan dan performa karet alami maupun karet sintetis. Ada banyak jenis tanah liat, tapi montmorillonite mempunyai catatan panjang sebagai bahan anorganik paling penting yang ditambahkan sebagai pengisi ke dalam lateks alami (getah pohon karet) (Bukit, 2012).

d. Maleat Anhidrida
Maleat anhidrida (cis-butenadioat anhidrida, anhidrida toksilat, dihidro-2,5dioksofuran) memiliki rumus kimia $\mathrm{C}_{4} \mathrm{H}_{2} \mathrm{O}_{3}$. Dalam keadaan murni, maleat anhidrida tidak berwarna atau berwarna putih padat dan memiliki bau yang tajam. Maleat anhidrida biasa digunakan dalam penelitian polimer sebagai senyawa penghubung (kopling agent) karena mempunyai gugus polar dan non polar. Maleat anhidrida memiliki berat molekul 98,06 g/mol, larut dalam air, meleleh pada temperatur $57-60{ }^{\circ} \mathrm{C}$, mendidih pada $202{ }^{\circ} \mathrm{C}$ dan specifik gravity $1,5 \mathrm{~g} / \mathrm{cm}^{3}$. Maleat anhidrida merupakan senyawa vinil tidak jenuh yang merupakan bahan mentah dalam sintesa resin poliester, pelapisan permukaan karet, deterjen, bahan aditif dan minyak pelumas, plastisizer dan kopolimer. Maleat anhidrida mempunyai sifat kimia yang khas yaitu adanya ikatan etilenik dengan gugus karbonil di dalamnya, ikatan ini berperan dalam reaksi adisi senyawa organik (Wirjosentono, 2013).

Maleat anhidrida dapat dibuat dari asam maleat, seperti reaksi berikut ini :

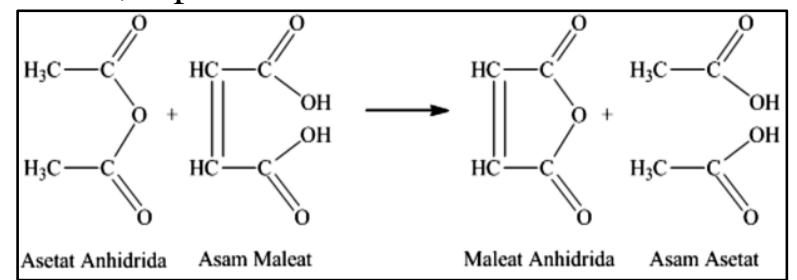

Gambar 2.2 Pembentukan Maleat Anhidrida

\section{e. Benzoil Peroksida}

Senyawa ini merupakan tipe inisiator yang sering digunakan. Berikut adalah rumus dan struktur kimia benzoil peroksida :

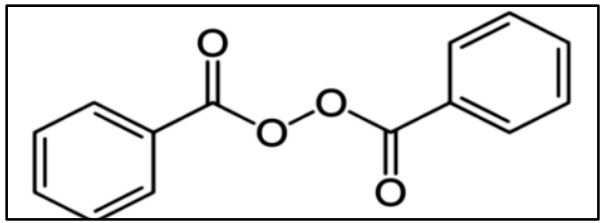

\section{Gambar 2.3 Rumus dan Struktur Kimia Benzoil Peroksida}

Senyawa ini tidak stabil terhadap panas dan dapat terurai menjadi radikal-radikal pada suhu tertentu dan laju yang tergantung pada strukturnya, mengalami homolisis termal 
untuk membentuk radikal-radikal benzoiloksi. Radikal benzoil mungkin menjalani berbagai reaksi selain beradisi ke monomer, termasuk rekombinasi, dekomposisi ke radikal fenil dan karbon dioksida dan kombinasi radikal. Reaksi-reaksi sekunder karena adanya efek molekul pelarut yang mengikat (efek sangkar) akibatnya konsentrasi inisiator berkurang (Wirjosentono, 2013). Reaksi hidrolisis BPO akibat panas dapat digambarkan seperti berikut:

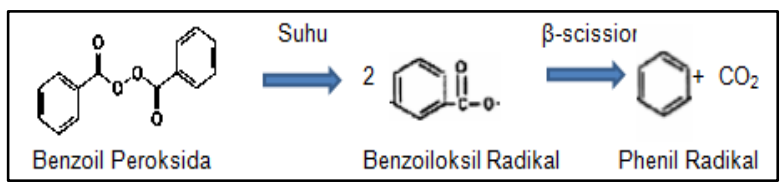

Gambar 2.4 Reaksi Hidrolisis Penzoil Peroksida

\section{f. Toluene}

Toluene mempunyai rumus molekul $\mathrm{C}_{7} \mathrm{H}_{8}$ dengan titik lebur $-93{ }^{\circ} \mathrm{C}$, titik didih $110,6{ }^{\circ} \mathrm{C}$ dan dikenal dengan nama Metil Benzene/Fenil Metana. Toluene merupakan liquid berbasis water-insoluble dengan bau pengencer cat yang khas. Toluene bereaksi secara normal sebagai hidrokarbon aromatik dan gugus metil dalam Toluene bereaksi 25 kali lebih reaktif dari pada Benzene.

Dengan bahan pereaksi, gugus metil dalam Toluene akan bereaksi dan mengalami oksidasi. Penambahan Toluene sebesar 10\% sebagai pengembang molekul karet yang sangat berpengaruh baik pada efektifitas degradasi partikel karet. Struktur Toluene dapat dilihat pada gambar 2.5:

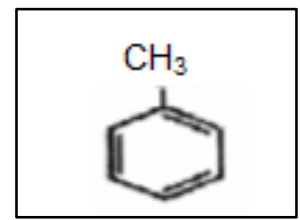

Gambar 2.5 Struktur Toluene

\section{g. Carbon black}

Carbon black (karbon hitam) secara umum digunakan dalam industri karet sebagai bahan pengisi (filler) yang dapat memberikan warna hitam, dan meningkatkan sifat mekanik produk karet alam. Konsumsi carbon black pada industri ban karet mencapai $70 \%$, sementara $20 \%$ digunakan untuk produk karet non-ban dan sisanya sebesar $10 \%$ digunakan untuk industri karet khusus (Ali, dkk. 2014).

Carbon black dapat diartikan sebagai salah satu bahan kimia yang paling stabil yang berbentuk seperti serbuk yang sangat halus dengan luas permukaan sangat besar dan hanya terdiri dari atom carbon. Selain digunakan sebagai penguat bahan karet, carbon black juga sering digunakan sebagai pigment hitam, serta konduktivitasnya digunakan dalam beberapa alat elektrik (Ali, dkk. 2014). Carbon black adalah filler yang paling efisien dengan ukuran partikel, kondisi permukaan dan sifat lain yang dapat divariasikan secara luas.

h. Degradasi Polipropilena dengan Benzoil Peroksida

Polipropilena adalah suatu polimer atau makromolekul rantai panjang yang mempunyai derajat polimer yang tinggi. Polipropilena termasuk polimer termoplastik yang akan lunak bila dipanaskan dan mengeras kembali bila dingin. Pada pengolahannya suhu pemanasan dibantu dengan adanya suatu inisiator peroksida, seperti benzoil peroksida polimer ini akan mengalami degradasi, yaitu terjadi pemutusan pada rantai utama. Pada penelitian ini degradasi polipropilena dilakukan dengan tujuan memperoleh polipropilena yang mempunyai bobot molekul lebih rendah dan rantai lebih pendek. Polipropilena dengan bobot molekul rendah dan rantai lebih pendek ini diharapkan setelah digrafting dengan maleat anhidrida, akan lebih mudah bereaksi dengan gugus hidroksil selulosa dan masuk keantara serat-serat selulosa dalam partikel.

Pada tahap awal reaksi karena pengaruh panas inisiator benzoil peroksida terdekomposisi secara homolitik membentuk radikal "RO•". Selanjutnya radikal ini akan menarik sebuah atom hidrogen dari molekul polipropilena sehingga terbentuk makromolekul radikal tertier "3P•". Kemudian makromolekul radikal tertier ini mengalami pemutusan rantai pada posisi $\beta$ sehingga rantai polipropilena semakin pendek dengan bobot molekul turun serta viskositas intrinsik turun dan proses ini akan terus berlanjut bila tidak 
ada terminasi rantai sesuai dengan mekanisme reaksi di bawah ini: (Nasution, 2012)

Dekomposisi dari Benzoil Peroksida

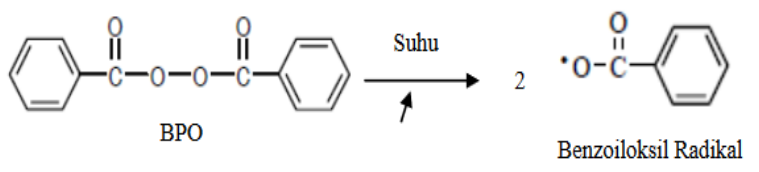

Inisiasi : Penarikan Atom Hidrogen

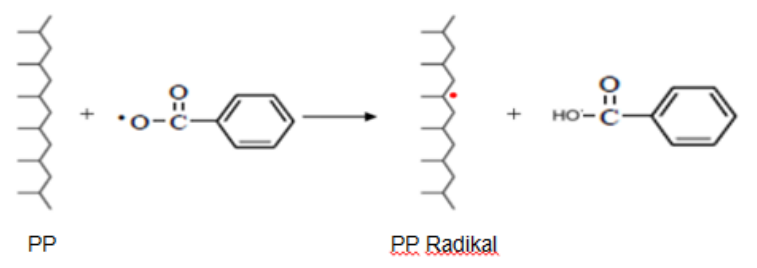

Pemutusan Rantai $\beta$ :

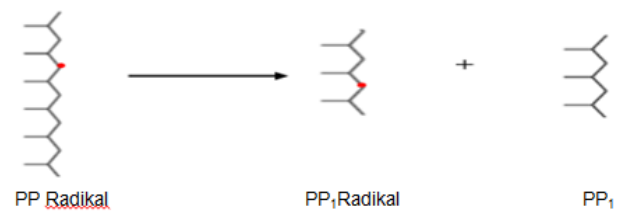

Terminasi :

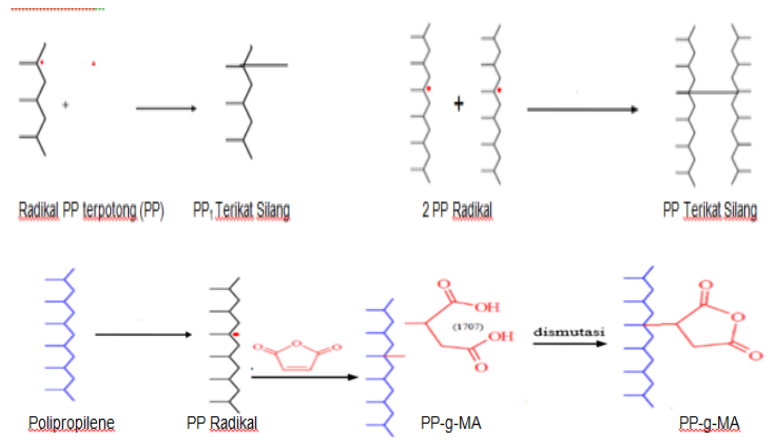

Gambar 2.6. Mekanisme Reaksi Dekomposisi BPO, Penarikan Atom Hidrogen Polipropilena, Terminasi, dan Grafting Maleat Anhidrid pada Senyawa Polipropilena oleh suatu Peroksida

\subsection{Bahan Pengisi (Filler)}

Bahan pengisi diklasifikasikan menjadi dua, yaitu carbon black dan bahan pengisi non-black atau biasa disebut pengisi berwarna. Setiap bahan pengisi, baik yang black atau non-black memiliki derajat keaktifan tersendiri. Klasifikasi bahan pengisi (filler) berdasarkan fungsinya dibagi menjadi dua jenis (Ali, dkk. 2014), yaitu:

1. Reinforcing filler, yaitu filler yang tidak hanya berfungsi sebagai bahan pengisi tetapi juga akan berpengaruh terhadap sifat-sifat fisik karet dan akan menambah kekuatan tarik dan daya tahan terhadap gesekan. Contohnya: carbon black, magnesium karbonat, $\mathrm{ZnO}$.

2. Inert filler, yaitu filler yang hanya berfungsi sebagai penambah volume saja. Contohnya : $\mathrm{CaCO}_{3}$, kaolin, $\mathrm{BaSO}_{4}$.

Berdasarkan keaktifannya, bahan pengisi (filler) dibagi menjadi dua golongan, yaitu golongan bahan pengisi (filler) aktif (bahan pengisi penguat) dan golongan bahan pengisi (filler) tidak aktif (Ali, dkk. 2014). Selain itu, penambahan bahan pengisi (filler) tidak aktif hanya akan menambah kekerasan dan kekakuan pada produk karetnya, tetapi kekuatan dan sifat lainnya akan berkurang. Harga bahan pengisi (filler) tidak aktif lebih murah dibandingkan dengan bahan pengisi (filler) aktif, sehingga menyebabkan bahan pengisi (filler) tidak aktif digunakan dalam kuantitas yang lebih kecil terutama untuk menekan harga produk karet yang dihasilkan (Ali, dkk, 2014). Bahan pengisi (filler) yang baik adalah bahan pengisi yang bersifat inert (tidak ikut bereaksi) terhadap komponen lain, tidak mudah terbakar, dan memiliki luas permukaan spesifik yang luas. Pada umumnya, bahan pengisi (filler) yang digunakan terdiri dari campuran dua komponen. Kemampuan filler untuk memperbaiki sifat vulkanisat dipengaruhi oleh tipe elastomer, sifat alami filler, dan jumlah filler yang digunakan (Ali, dkk. 2014).

\subsection{Kompatibiliser (Compatibilizer)}

Untuk meningkatkan daya rekat permukaan bahan pada proses pencampuran dan menstabilkan kondisi morfologi dalam campuran polimer, berbagai metode telah dikembangkan. Secara umum, ada dua keadaan untuk meningkatkan kompatibilitas yaitu immiscible blends dan reactive blending, immiscible blends yakni dengan cara menambahkan polimer yang sudah difungsionalisasi sehingga mampu 
meningkatkan interaksi tertentu atau bereaksi secara kimia. Fungsionalisasi dapat dilakukan sebelum pencampuran polimer atau sekaligus dalam proses pencampuran dalam mesin pencampur (internal mixer) sehingga akan terbentuk blok atau graft-copolymers, halogenasi, sulfonasi, formasi hydroperoxide, dan lain-lain. Perkembangan terakhir dalam produksi campuran polimer menggunakan metode reactive blending yang bergantung pada pembentukan langsung kopolimer atau interaksi Polimer. Biasanya polimer reaktif dapat dihasilkan oleh radikal bebas copolymerisation atau disebut pencangkokan reaktif (reactive grafting) kepada rantai induk polimer. Gugus fungsional, seperti anhydride, epoxy, oxazoline, dan yang terikat pada rantai induk polimer sering dipilih untuk reactive blending, gugus fungsional pencampuran polimer (kompatibilisasi) dalam reactive blending (Bukit, 2012).

Penambahan zat kompatibiliser yang memiliki interaksi spesifik atau reaksi kimia dengan komponen campuran polimer blok atau graft-copolymer dan zat reaktif dengan berat molekul rendah termasuk dalam kategori ini. Penentuan pilihan blok atau graft-copolymer sebagai zat kompatibiliser didasarkan pada sifat kereaktifan dan kemudah-campuran (miscibility) dengan campuran polimer. Fungsionalisasi polimer yang mempunyai kemiripan struktur dengan salah satu jenis polimer campuran dapat digunakan sebagai zat kompatibiliser dalam pencampuran polimer.

\section{METODOLOGI PENELITIAN}

\subsection{Metode Penelitian}

Berikut adalah metode pembuatan termoplastik elastomer terdiri dari 4 (empat) tahap, yaitu (Sukatik, 2012):

1. Degradasi polipropilena dengan inisiator Benzoil Peroksida.

2. Grafting Polipropilena dengan Maleat Anhidrid (PP-g-MA).

3. Pencampuran PP-g-MA dengan Karet Alam.

4. Pencampuran carbon black filler.

\subsection{Analisa Data yang dilakukan}

Berikut adalah analisa data yang dilakukan dalam penelitian ini :

1. Uji kestabilan

Sifat fisik yang diukur adalah densitas komposit dibandingkan dengan densitas air.

2. Morfologi permukaan campuran

Morfologi permukaan campuran PP-gMA dengan NR dilakukan untuk melihat struktur mikro pori-pori dan bentuk partikel di bawah Scanning Electron Microscopy (SEM) dengan perbesaran 2 juta kali dengan resolusi mencapai 0,1 $0,2 \mathrm{~nm}$, dimana hasilnya dapat menentukan keseragaman struktur permukaan termoplastik elastomer yang dapat digunakan.

3. Pengujian karakteristik

Pengujian karakteristik meliputi pengukuran fisik (densitas dan morfologi campuran) dan pengukuran mekanik (uji kuat tarik, uji perpanjangan putus dan uji ketahanan minyak).

\section{HASIL DAN PEMBAHASAN}

\subsection{Data Hasil Uji Campuran}

Termoplastik elastomer itu sendiri dibuat melalui pencampuran PP-g-MA dengan Natural Rubber ditambah dengan carbon black filler. Termoplastik Elastomer yang dihasilkan di analisis secara visual dengan data hasil pengamatan seperti tabel berikut ini :

Tabel 2. Data Hasil Uji Campuran

\begin{tabular}{|c|c|c|c|c|}
\hline \multirow{2}{*}{ Komposisi } & \multicolumn{4}{|c|}{ Campuran (\% wt) } \\
\hline & $\mathrm{S}_{1}$ & $\mathrm{~S}_{2}$ & $\overline{S_{3}}$ & $\mathrm{~S}_{4}$ \\
\hline PP-g-MA & లి & లి & ల & \& \\
\hline NR & 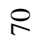 & $\infty$ & 8 & to \\
\hline Carbon Black & 0 & $\alpha$ & $\nabla$ & 6 \\
\hline \multicolumn{5}{|l|}{ Sifat Fisik } \\
\hline $\begin{array}{l}\text { Densitas } \\
\text { Bulk/Curah }(\mathrm{g} / \mathrm{ml})\end{array}$ & $\underset{\Xi}{\beth}$ & है. & है & $\hat{\sigma}$ \\
\hline \multicolumn{5}{|l|}{ Sifat Mekanik } \\
\hline $\begin{array}{l}\text { Uji ketahanan } \\
\text { minyak }(\%)\end{array}$ & 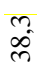 & ง & $\stackrel{+}{\sigma}$ & $\stackrel{1}{\simeq}$ \\
\hline
\end{tabular}




\begin{tabular}{|c|c|c|c|c|}
\hline \multirow{2}{*}{ Komposisi } & \multicolumn{4}{|c|}{ Campuran $(\% \mathrm{wt})$} \\
\hline & $\mathrm{S}_{1}$ & $\mathrm{~S}_{2}$ & $\mathrm{~S}_{3}$ & $\mathrm{~S}_{4}$ \\
\hline $\begin{array}{l}\text { Uji Perpanjangan } \\
\text { Putus }(\%)\end{array}$ & $\stackrel{\infty}{\stackrel{\infty}{N}}$ & $\begin{array}{l}8 \\
\text { Nิ }\end{array}$ & $\frac{0}{6}$ & $\begin{array}{l}8 \\
8 \\
0 \\
1\end{array}$ \\
\hline $\begin{array}{l}\text { Uji Kuat Tarik } \\
\left(\mathrm{N} / \mathrm{mm}^{2}\right)\end{array}$ & $\frac{9}{2}$ & ふू & 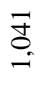 & $\stackrel{2}{2}$ \\
\hline
\end{tabular}

Berikut adalah tabel Standar British Plastic Federation (BPF) terutama untuk sifat kekuatan tarik dan densitas dari termoplastik elastomer :

Tabel 4.3 Standar British Plastic Federation (BPF)

\begin{tabular}{|c|c|}
\hline $\begin{array}{c}\text { Sifat Termoplastik } \\
\text { Elastomer }\end{array}$ & $\begin{array}{c}\text { Range } \text { Standar } \\
\text { BPF }\end{array}$ \\
\hline Kekuatan tarik $\left(\mathrm{N} / \mathrm{mm}^{2}\right)$ & $0,50-2,4$ \\
\hline Density $(\mathrm{g} / \mathrm{ml})$ & $0,91-1,3$ \\
\hline
\end{tabular}

\subsection{Sifat Morfologi Permukaan Campuran}

Sifat morfologi komposit PP/NR dengan penambahan carbon black filler dapat dilihat menggunakan Scanning Electron Microscope (SEM) merk JEOL 6510LA yang dilaksanakan di Universitas Negeri Jakarta (UNJ). Gambar 7 dan 8 menunjukkan hasil analisa struktur mikro antara komposit yang ditambahkan filler dengan komposit yang tidak ditambah filler.

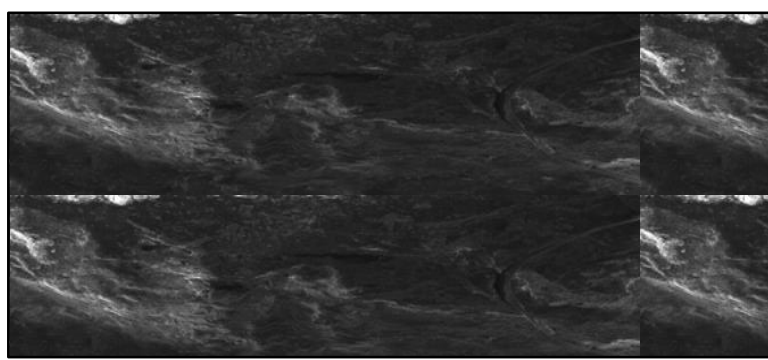

Gambar 4.1. Struktur Morfologi Komposit dengan Penambahan Filler

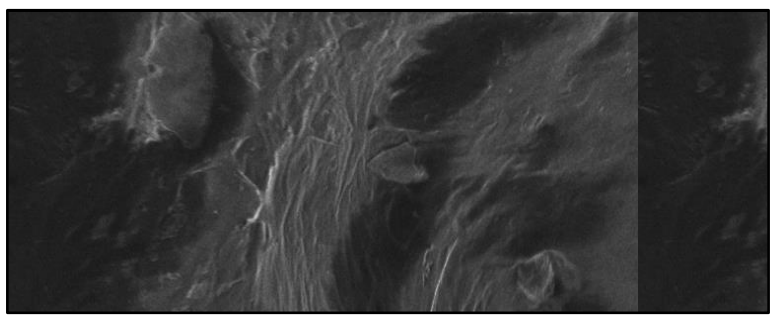

Gambar 4.2 Struktur Morfologi Komposit Tanpa Penambahan Filler
Pada Gambar 4.1 terlihat bahwa komposit yang ditambahkan filler terlihat lebih kasar, hal tersebut merupakan konsekwensi dari pemakaian carbon black filler yang mempunyai sifat keras dengan bentuk fisik berupa partikel-partikel kecil dengan ukuran partikel 200 mesh. Sedangkan pada komposit yang tidak ditambahkan filler morfologi permukaannya terlihat lebih halus (smooth), hal tersebut dikarena partikel karet yang bersifat lentur dan lunak dibandingkan dengan komposit yang ditambah dengan filler.

\subsection{Pengaruh Variasi Komposisi Carbon Black terhadap Sifat Kuat Tarik Komposit}

Berdasarkan data pada Tabel 4.2, didapat grafik pengaruh variasi jumlah carbon black filler terhadap sifat kuat tarik komposit yang dapat dilihat pada Gambar 4.3.

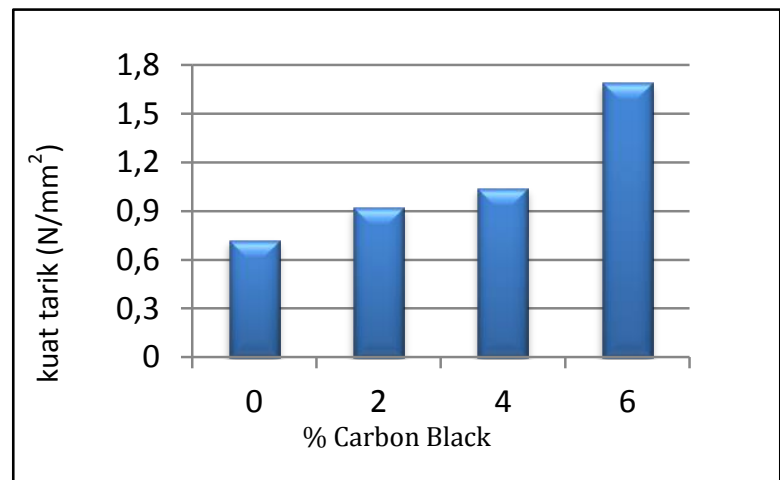

\section{Gambar 4.3 Grafik Pengamatan Variasi Carbon Black Filler terhadap Uji Kuat Tarik}

Dari grafik dapat dilihat nilai sifat kuat tarik termoplastik elastomer yang dihasilkan telah memenuhi range standar sifat kuat tarik termoplastik elastomer berdasarkan British Plastic Federation (BPF) $\left(0,5-2,4 \mathrm{~N} / \mathrm{mm}^{2}\right)$, dimana semakin banyak filler yang digunakan kekuatan tariknya semakin meningkat. Kenaikan sifat tersebut adalah konsekwensi dari pemakaian carbon black yang relatif tidak mempunyai sifat elastis sehingga pada saat terjadi perekatan adhesi antar fasa tersebut akan mengikat kuat dan mengeras karena terisi oleh partikel filler. Meskipun demikian terdapat titik lemah pada batas fasa komposit 
tersebut, dimana ikatan antara permukaan molekul karet, molekul polipropilena dan partikel filler terdapat batas permukaan yang mempunyai sifat fisik yang berbeda sehingga dapat menyebabkan pemisahan fasa pada kondisi tertentu (saat diberikan tegangan tarik maksimum) yang dapat menyebabkan sifat mekanik paduan menjadi kurang baik. Untuk campuran komposit dengan kekuatan tarik terbaik adalah pada campuran keempat dengan rasio $\mathrm{PP} / \mathrm{NR} / \mathrm{CB}=30 \% / 64 \% / 6 \%$ wt sebesar $1,79 \mathrm{~N} / \mathrm{mm}^{2}$. Namun hal ini juga sangat dipengaruhi oleh teknik pencampuran. Pada campuranPP/NR komponen PP dan filler $\mathrm{CB}$ adalah fasa terdistribusi dan komponen NR adalah fasa matrik. Ukuran partikel yang semakin kecil dan dispersi yang semakin merata dari fasa terdistribusi dapat menghasilkan sifat kekuatan tarik campuran yang semakin meningkat.

\subsection{Pengaruh Variasi Komposisi Carbon Black terhadap Sifat Perpanjangan Putus Komposit}

Berikut adalah grafik hubungan pengaruh variasi jumlah carbon black filler terhadap sifat perpanjangan putus komposit yang dapat dilihat pada Gambar 4.4.

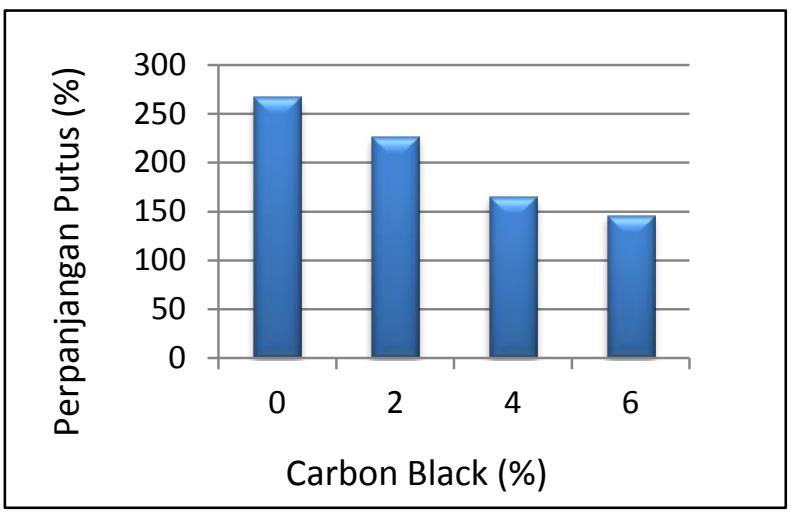

Gambar 4.4 Grafik Pengamatan Variasi Carbon Black Filler terhadap Uji Perpanjangan Putus

Dari grafik di atas dapat kita lihat bahwa variasi jumlah carbon black filler mempengaruhi sifat perpanjangan putus yang dimiliki komposit, dimana semakin banyak carbon black filler yang digunakan maka sifat perpanjangan putus campuran akan semakin rendah. Penurunan sifat tersebut adalah akibat dari pemakaian carbon black yang relatif lebih banyak dimana $\mathrm{CB}$ tidak mempunyai sifat elastis sehingga perekatan antar molekul yang ada di dalam campuran pada saat penarikan berkurang, dan menyebabkan berkurangnya sifat perpanjangan putus komposit. Untuk campuran komposit dengan sifat perpanjangan putus terbaik adalah pada campuran pertama dengan rasio $\mathrm{PP} / \mathrm{NR} / \mathrm{CB}=$ $30 \% / 70 \% / 0 \%$ wt sebesar $277,38 \%$.

\subsection{Pengaruh Variasi Komposisi Carbon Black terhadap Sifat Ketahanan Minyak dari Komposit}

Berdasarkan data pada tabel 4.2, maka didapat grafik pengaruh variasi jumlah carbon black filler terhadap sifat ketahanan minyak dari komposit yang dapat dilihat pada gambar 4.5. Grafik data hasil uji ketahanan minyak.

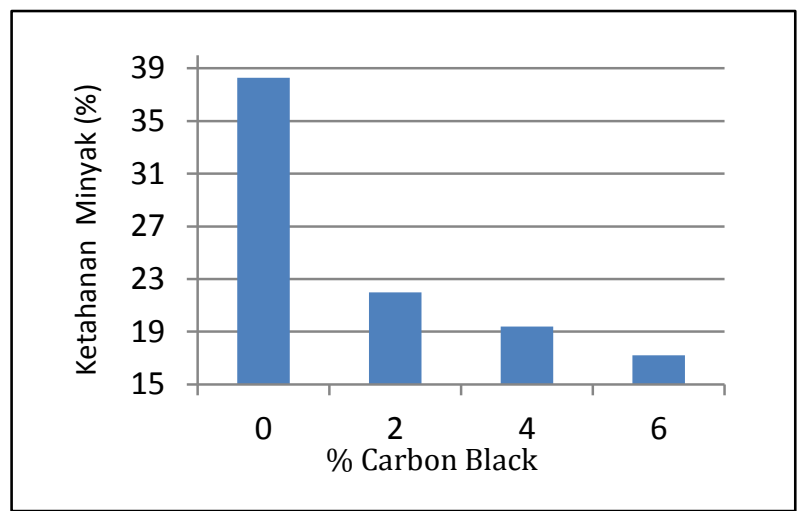

\section{Gambar 4.5 Grafik Pengamatan Variasi Carbon Black Filler terhadap Uji Ketahanan Minyak}

Analisa ketahanan terhadap minyak dilakukan dengan menggunakan minyak IRM 903 (tinggi kandungan napthenik/aromatik). Dari grafik dapat dilihat bahwa semakin banyak campuran filler maka ketahanan terhadap minyak semakin menurun. Hal ini menunjukkan bahwa carbon black filler yang tercampur dalam komposit menyebabkan menurunnya adhesi antar fasa pada saat minyak IRM mengisi diantara molekul komposit. Komposisi terbaik untuk komposit adalah pada campuran $\mathrm{PP} / \mathrm{NR} / \mathrm{CB}=$ $30 \% / 70 \% / 0 \%$ wt sebesar 38,3\%. Dimana nilai 
ketahanan minyak juga dipengaruhi oleh berat awal dan penimbangan komposit.

\subsection{Pengaruh Variasi Komposisi Carbon Black terhadap Nilai Densitas Campuran}

Berdasarkan data pada tabel 4.2, maka didapat grafik pengaruh variasi jumlah carbon black filler terhadap nilai densitas curah komposit yang dapat dilihat pada gambar 4.6.

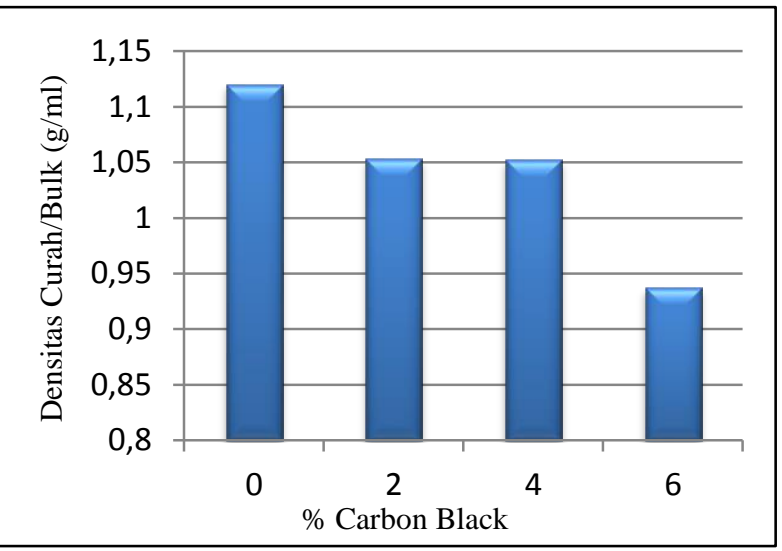

Gambar 4.6 Grafik Pengamatan Variasi Carbon Black Filler terhadap Nilai Densitas Bulk/Curah

Peningkatan sifat kerapatan terjadi pada komposisi CB 0\% wt massa, yaitu sebesar $1,120 \mathrm{~g} / \mathrm{ml}$, sifat kerapatan tersebut mengalami penurunan terendah pada komposisi CB 6\% wt massa, yaitu sebesar $0,937 \mathrm{~g} / \mathrm{ml}$, hal ini menunjukkan bahwa kompatibilisasi yang relatif baik antara $\mathrm{PP} / \mathrm{NR} / \mathrm{CB}$ terjadi pada komposisi $\mathrm{CB}$ yang relatif rendah untuk rasio $\mathrm{PP} / \mathrm{NR}$ 30/70. Kemungkinan penurunan sifat kerapatan terjadi karena rongga yang terbentuk akibat dari sifat karateristik fasa campuran yang tidak dapat campur (immiscible blend), Selain itu diperkirakan karena pengaruh teknik pencampuran komposit. Berdasarkan standar densitas termoplastik nilai densitas yang dihasilkan sesuai dalam range standar densitas termoplastik elastomer berdasarkan British Plastic Federation (BPF), yaitu 0,91-1,3 g/ml.

Berikut adalah Tabel 4.4 Perbandingan Sifat Mekanik Berbagai Sistem CampuranPP/NR pada Rasio Massa :
Tabel 4.4. Perbandingan Sifat Mekanik Berbagai Sistem Campuran PP/NR

\begin{tabular}{|c|c|c|}
\hline \multirow[b]{2}{*}{ Sistem Campuran } & \multicolumn{2}{|c|}{ Sifat Mekanik } \\
\hline & $\begin{array}{c}\text { Kuat } \\
\text { Tarik } \\
\left(\mathrm{N} / \mathrm{mm}^{2}\right) \\
\end{array}$ & $\begin{array}{c}\text { Perpanjangan } \\
\text { Putus } \\
(\%) \\
\end{array}$ \\
\hline $\begin{array}{lr}\text { NR/PP } & \text { dengan } \\
\text { kompatibilizer } & \text { MA-g- } \\
\text { PP dan penambahan } \\
\text { carbon balck filler } \\
\text { dengan } \\
\text { vulkanisasi metoda } \\
\text { (Bahruddin, dkk. 2010) } \\
\end{array}$ & 9,8 & 413 \\
\hline $\begin{array}{l}\text { NR/PP dengan inisiator } \\
\text { potasium persulfat } 2 \% \\
\text { dan SDS } 1 \% \\
\text { (Suhardjo, dkk. 2011) }\end{array}$ & 4,7 & 41,93 \\
\hline $\begin{array}{l}\text { NR/PP dengan Sulfur } 3 \\
\text { phr dan } 5 \text { phr di } \\
\text { vulkanisasi dinamik } \\
\text { dalam internal mixer } \\
\text { (Bahruddin, dkk. 2007) }\end{array}$ & 1,5 & 70 \\
\hline $\begin{array}{lr}\text { NR/PP } & \text { dengan } \\
\text { penambahan } & \text { carbon } \\
\text { black } & \text { filler } \\
\text { menggunakan metoda } \\
\text { grafting (Indah, dkk. } \\
2017 \text { ) }\end{array}$ & 1,66 & 268,36 \\
\hline $\begin{array}{l}\text { Karakteristik TPE dari } \\
\text { Karet Alam dan PP } \\
\text { dengan PP terdegradasi } \\
\text { (penelitian ini) }\end{array}$ & 1,79 & 277,38 \\
\hline
\end{tabular}

\section{KESIMPULAN DAN SARAN \\ 5.1 Kesimpulan}

Dari pembahasan tersebut, maka kesimpulan dari penelitian ini, yaitu :

1. Campuran komposit polipropilena, karet alam dan carbon black filler yang dihasilkan memenuhi range standar sifat kuat tarik termoplastik elastomer, yaitu 0,5$2,4 \mathrm{~N} / \mathrm{mm}^{2}$ dan memenuhi range standar densitas termoplastik elastomer, yaitu 0,91 $1,3 \mathrm{~g} / \mathrm{ml}$ berdasarkan British Plastic Federation (BPF) dengan kelebihan dan kekurangan masing-masing setiap komposit.

2. Berdasarkan pengamatan struktur mikro morfologi permukaan menggunakan 
Scanning Electron Microscope (SEM) menunjukkan bahwa filler tersebar merata di dalam komposit. Nilai kuat tarik terbaik didapatkan pada campuran keempat sebesar $1,79 \mathrm{~N} / \mathrm{mm}^{2}$ dengan rasio massa PP/NR/CB $=30 \% / 64 \% / 6 \%$ wt, sedangkan perpanjangan putus terbaik sebesar 277,38\% didapatkan pada campuran kesatu dengan rasio massa $\mathrm{PP} / \mathrm{NR} / \mathrm{CB}=$ $30 \% / 70 \% / 0 \%$ wt.

\section{DAFTAR PUSTAKA}

Agus.S, Indah., Nasir, S., Emilia A., Tuty. 2017. Pengaruh Pencampuran Carbon Black Filler Terhadap Komposit Polypropylene dan Karet Alam Sebagai Elastomer Termoplastik dengan Metode Grafting. Jurnal Patra Akademika Vol.8 No.2, Desember 2017, Hal:53-61.

Ali, F., R. D., M. Mezal, D. H., Valencia. 2014. Pengaruh Penambahan Zeolit dan Kulit Kerang Darah Terhadap Sifat Mekanis Rubber Compound. Jurnal Teknik Kimia No. 3, Vol. 20, Agustus 2014.

Bahruddin, Sumarno, Wibawa,G., Soewarno, N.. 2007. Morfologi dan Properti Campuran Karet Alam/Polypropylene yang Divulkanisasi Dinamik dalam Internal Mixer", Reaktor. Vol. 11, No. 2, Desember 2007, Hal : 71-77.

Bahruddin, Zahrina, I., Amraini, S. Z.. 2010. Pengaruh Filler Carbon Black Terhadap sifat dan Morfologi Komposit Natural Rubber/Polypropylene. Jurnal Teknik Kimia Indonesia Vol. 9, No. 2. Agustus 2010, 62-68. Bukit,N.,2012,'’http://repository.usu.ac.id/bitst ream/handle/123456789/61935/BAB\%20II\%2 0Tinjauan $\% 20$ pustaka.pdf? sequence $=2$, diakses tanggal 15 Oktober 2015.

Deswita, Sudirman, Karo, A. K., Sugiantoro, S., Handayani, A.. 2006. Pengembangan Elastomer Thermoplastik Berbasis Karet Alam dengan Polietilen dan Polipropilen untuk Bahan Industri. Indonesian Journal of
Materials Science, Vo. 8, No. 1 Oktober 2006, Hal : 52-57, ISSN : 1411-1098.

Halimatuddahliana, Ismail, H., 2003. Properties of Thermoplastic Elastomer Based on PP/EPDM/ENR25 and PP/EPDM/NR Blends. Jurnal Teknologi, 39(A).97-106, University Teknologi Malaysia.

Halimatuddahliana, Surya, I., Maulida. 2008. Modifikasi Bahan Termoplastik elastomer Polipropilena/Karet Alam (NR/PP) dengan Proses Pemvulkanisasian Dinamik. Jurnal Penelitian Rekayasa, Volume 1, Nomor 2, Des. 2008.

Hidayani, T. R..2010. Penentuan Derajat Grafting dan Fraksi Gel Dari Polipropilena Terdegradasi yang Difungsionalisasikan Dengan Maleatanhidrida. http://epository.usu.ac.id/bitstream/handle/123 456789/61935/BAB\%20II\%20Tinjauan\%20pu staka.pdf? sequence $=2$, diakses tanggal 15 Oktober 2015.

Nasution,D.Y. 2012. http://repository.usu.ac.id/bitstream/handle/12 3456789/61935/BAB\%20II\%20Tinjauan\%20p ustaka.pdf?sequence $=2$, diakses tanggal 15 Oktober 2015.

Sondari, D., Haryono, A., Ghozali, M., Randy, A., Suhardjo, K. A., Basuki, A., Surasno. 2010. Pembuatan Termoplastik elastomer Menggunakan Inisiator Potassium Persulfate dan Ammonium Peroxydisulfate", Indonesian Journal of Materials Science, Vol. 12, No. 1 Oktober 2010, Hal : 41- 45, ISSN : 1411-1098.

Sudirman, Handayani, A., Darwinto, T., Yulius S.P.P, T., Surnani, A., Marlijanti, I. 2000. Strukturmikro dan Sifat Mekanik Komposit Termoplastik elastomer-Timbal Oksida. J. Mikroskopi dan Mikroanalisis, Vol. 3, No.1, 2000, ISSN : 1410-5594.

Suhardjo, K. A., Basuki, A., Surasno, Randi, A., Sondari, D.. 2011. Modification of Natural Rubber to Thermoplastic Elastomer Material. 
Jurnal Riset Industri, Vol. V, No. 3, 2011, Hal : 283-292.

Sukatik. 2012. The Characteristic of the Elastomer Thermoplastic from Polystyrene and Height Concentrate Natural Rubber Latex Prepared by Emulsion Method", Poli Rekayasa Vol. 8, Nomor 1, Oktober 2012, ISSN : 1858-3709.

Wirjosentono,B.2013."http://repository.usu.ac. $\mathrm{id} /$ bitstream/handle/123456789/61935/BAB\% 20II\%20Tinjauan \%20pustaka.pdf? sequence $=2$ , diakses tanggal 15 Oktober 2015.

-Standar Density dan Tensile Strenght Termoplastik elastomer., www.bpf.co.uk, di akses tanggal 5 Juli 2016. 
P-ISSN: 2089-5925 E-ISSN: 2621-9328

Antrant

Jurnal Teknik Patra Akademika

PATA

LII I 